\title{
What is frugal innovation? Three defining criteria
}

Timo Weyrauch ${ }^{*}$ and Cornelius Herstatt

\begin{abstract}
Recently, the innovation management literature has witnessed a rising interest in the so-called frugal innovation. The term was initially discussed in the context of emerging markets, giving non-affluent customers opportunities to consume affordable products and services suited to their needs. However, the meaning of frugal innovation is fuzzy. Further, the increasing appearance of frugal innovation in developed markets challenges earlier definitions that often characterised frugal innovation particularly in the context of emerging markets. So far, it has not been clear what differentiates frugal innovation from other innovation types. Thus, we need criteria that make it possible to determine what frugal innovation is and what is not. In order to determine a clear definition, we choose a multimethod approach, conduct a literature review, and interview 45 managers from companies and researchers from different research institutes. On the basis of the results, we define three criteria for frugal innovation: substantial cost reduction, concentration on core functionalities, and optimised performance level. We contribute to the literature by refining the meaning of frugal innovation. We also enable organisations to better deal with the challenge of developing frugal innovation in both emerging and developed markets.

Keywords: Frugal innovation, Frugal engineering, Reverse innovation, Cost innovation, Low-cost innovation, Goodenough innovation, Jugaad innovation, Constraint-based innovation, Resource-constrained innovation, Gandhian innovation
\end{abstract}

\section{Introduction}

Frugal innovations mainly originated in the context of emerging markets. The main idea was to develop products and services that fit these markets' special needs and requirements and that were cheap enough to give non-affluent customers opportunities for consumption (Hart and Christensen 2002; Prahalad and Hart 2002; Wooldridge 2010; Soni and Krishnan 2014). In the meantime, frugal innovations have also found their way into developed markets (The Economist 2012) and are often referred to as reverse innovation (Govindarajan and Trimble 2012; Immelt et al. 2009; von Zedtwitz et al. 2015). Several examples have been written about frugal innovation. For instance, Rao (2013) discusses 30 different frugal innovations. Well-known examples include the Tata Nano (Ray and Ray 2011; Tiwari and Herstatt 2014)

\footnotetext{
* Correspondence: timo.weyrauch@tuhh.de

Institute for Technology and Innovation Management, Hamburg University of Technology, Am Schwarzenberg-Campus 4, 21073 Hamburg, Germany
}

and the handheld, pocket-sized ultrasound device GE Vscan (Govindarajan and Trimble 2012).

But what does frugal innovation mean? What differentiates frugal innovation from other innovation types? Publications in the field of frugal innovation often provide definitions that rely on the possible attributes of frugal innovation (for instance, significantly lower costs, ease of use, limited features, and low impact on the environment). Other articles propose a theoretical understanding of frugal innovation and seek to develop frameworks to distinguish frugal innovations from terms such as low-cost innovation, good-enough innovation, jugaad innovation, frugal engineering, constraint-based innovation, Gandhian innovation, or reverse innovation (Bhatti and Ventresca 2013; Brem and Wolfram 2014; Ostraszewska and Tylec 2015; Zeschky et al. 2014). Current frameworks and definitions help us to better understand frugal innovation and what it could look like. However, to date, we have lacked criteria for clearly defining frugal innovation. With this paper, we seek to 
answer the following question: which criteria apply that allow us to define frugal innovation?

To answer this question, we chose a multimethod approach. First, we conducted a literature review to identify attributes and characterisations of frugal innovation used in the literature. In step two, we interviewed 45 managers from companies and researchers from different research institutes that deal with frugal innovation in order to capture the term's practical meaning. By coding the results, we noted that most characteristics attributed to frugal innovation can be subsumed into three categories: cost reduction, core functionality, and performance level. On the basis of this finding, we deduced three criteria for frugal innovation: substantial cost reduction, concentration on core functionalities, and optimised performance level. We propose to characterise innovations as frugal if they meet all of these three criteria at the same time.

By defining these three criteria, our contribution to theory is a more precise understanding of frugal innovation. First, we suggest referring to an innovation as frugal only if all three criteria are met. Thus, these criteria can be used to check whether or not a certain innovation can be characterised as frugal. Second, the criteria help us to better understand why frugal innovations are different and why their development can be challenging: all three criteria must be met simultaneously. This has practical implications: to develop frugal innovations, all three criteria should be considered so as to identify the specific characteristics to make a new product or service frugal.

This paper is structured as follows. In the next section, we provide an overview of concepts and frameworks that distinguish frugal innovation from other innovation types. We then explain the methodology and outline our results. On the basis of our literature review and interviews, in the "Discussion" section, we deduce three criteria for frugal innovation. Finally, we point out theoretical and managerial implications, discuss potential limitations, and provide recommendations for further research.

\section{Background}

Several concepts and frameworks attempt to distinguish frugal innovation from other innovation types. Most are based on literature reviews (for an overview, see Table 1).

Cunha et al. (2014) examined literature streams in the field of scarcity and product innovation. They consider frugal innovation to be product innovation when there is a scarcity of affluent customers and distinguish it from bricolage, which is when material resources are scarce, and from improvisation, when time is scarce.
Brem and Wolfram (2014) seek to distinguish between frugal innovation and related terms such as frugal engineering, constraint-based innovation, Gandhian innovation, jugaad innovation, reverse innovation, catalytic innovation, grassroots innovation, and indigenous innovation. They introduce a conceptual framework based on a literature review of 363 explored articles. Their framework classifies frugal innovation and the related terms by using the three dimensions: sophistication, sustainability, and emerging market orientation. In their classification, compared to jugaad innovation or reverse innovation, frugal innovation has low to medium sophistication, medium sustainability, and medium emerging market orientation.

Zeschky et al. (2014) also analyse different resourceconstrained innovation types. They distinguish between frugal innovation, good-enough innovation, and cost innovation, conceptualising the distinctions between them. They classify frugal innovation via the criteria technical novelty and market novelty. In their view, frugal innovation has a higher technical novelty and a higher market novelty than good-enough innovation and cost innovation. Also, in their conceptualisation, cost innovation means the same for less, good-enough innovation means tailored for less, and frugal innovation means new for less. Ostraszewska and Tylec (2015) use a similar conceptualisation, with the criteria the same for less, adapted for less, and new for less to distinguish between cost innovation, jugaad innovation, Gandhian innovation, good-enough innovation, and frugal innovation. In their classification, the GE LOGIQ Book Ultrasound Machine is an example of frugal innovation (new for less), while the city car Tata Nano is an example of Gandhian innovation (adapted for less); elsewhere, the Tata Nano is used as a typical example of frugal innovation (Rao 2013; Tiwari and Herstatt 2014; Wooldridge 2010).

Soni and Krishnan (2014) review the literature on frugal innovation and propose, in their conceptual paper, looking at frugal innovation not as a monolithic entity. They introduce three frugal innovation types: frugal innovation as a mindset or way of life, as a process, and as an outcome in the form of products or services. Their approach aims at a typology of frugal innovation rather than focusing on distinctions between frugal innovation and other innovation types.

Basu et al. (2013) distinguish between frugal innovation and conventional innovation along four characteristics: driver, process, core capabilities, and location. The driver of frugal innovation is described by what do they need, in contrast to what would be nice to have; the latter relates to conventional innovation. The process is described as bottom-up in contrast to top-down. The core capability is functionality (rugged, lightweight, adaptable, and simple) 
Table 1 Distinguishing characteristics of frugal innovations

\begin{tabular}{|c|c|c|c|}
\hline & $\begin{array}{l}\text { Article, } \\
\text { authors }\end{array}$ & Distinguishing characteristics & $\begin{array}{l}\text { Distinguishing between frugal innovation and other innovation } \\
\text { types }\end{array}$ \\
\hline \multirow[t]{6}{*}{$\begin{array}{l}\text { Concepts and } \\
\text { frameworks to classify } \\
\text { frugal innovation }\end{array}$} & $\begin{array}{l}\text { Cunha et al. } \\
\text { (2014) }\end{array}$ & Field of scarcity & $\begin{array}{l}\text { - Frugal innovation: affluent customers are scarce. } \\
\text { - Bricolage: material resources are scarce. } \\
\text { - Improvisation: time is scarce. }\end{array}$ \\
\hline & $\begin{array}{l}\text { Brem and } \\
\text { Wolfram } \\
\text { (2014) }\end{array}$ & $\begin{array}{l}\text { Sophistication, sustainability, and } \\
\text { emerging market orientation }\end{array}$ & $\begin{array}{l}\text { - Frugal innovation has low to medium sophistication, medium } \\
\text { sustainability, and medium emerging market orientation. }\end{array}$ \\
\hline & $\begin{array}{l}\text { Zeschky et al. } \\
\text { (2014) }\end{array}$ & $\begin{array}{l}\text { Technical novelty and market novelty } \\
\text { Criteria: same for less, tailored for less, } \\
\text { and new for less }\end{array}$ & $\begin{array}{l}\text { - Frugal innovation has higher technical and higher market } \\
\text { novelty than good-enough innovation and cost innovation. } \\
\text { - Frugal innovation = new for less, cost innovation = same for less, } \\
\text { and good-enough innovation = tailored for less. }\end{array}$ \\
\hline & $\begin{array}{l}\text { Ostraszewska } \\
\text { and Tylec } \\
\text { (2015) }\end{array}$ & $\begin{array}{l}\text { Criteria: same for less, adapted for less, } \\
\text { and new for less }\end{array}$ & $\begin{array}{l}\text { - The GE LOGIQ Book Ultrasound Machine is an example of frugal } \\
\text { innovation (new for less); the Tata Nano (often used as a typical } \\
\text { example for frugal innovation) is considered an example of } \\
\text { Gandhian innovation (adapted for less). }\end{array}$ \\
\hline & $\begin{array}{l}\text { Soni and } \\
\text { Krishnan } \\
(2014)\end{array}$ & $\begin{array}{l}\text { Introducing three frugal innovation } \\
\text { types }\end{array}$ & $\begin{array}{l}\text { - Frugal innovation can be interpreted as a mindset or a way of } \\
\text { life, as a process, and as an outcome in the form of products or } \\
\text { services. }\end{array}$ \\
\hline & $\begin{array}{l}\text { Basu et al. } \\
\text { (2013) }\end{array}$ & $\begin{array}{l}\text { Introducing characteristics of frugal } \\
\text { innovation and conventional innovation }\end{array}$ & $\begin{array}{l}\text { - Frugal innovation } \\
\text { - Driver: what do they need } \\
\text { - Process: bottom-up } \\
\text { - Core capabilities: functionality (rugged, lightweight, } \\
\text { adaptable, simple) } \\
\text { - Location: developing markets, emerging markets. } \\
\text { - Conventional innovation } \\
\text { - Driver: what would be nice to have } \\
\text { - Process: top-down } \\
\text { - Core capabilities: desirability and design } \\
\text { - Location: developed markets. }\end{array}$ \\
\hline \multirow[t]{3}{*}{$\begin{array}{l}\text { Rules and principles of } \\
\text { frugal innovation }\end{array}$} & $\begin{array}{l}\text { Kumar and } \\
\text { Puranam } \\
\text { (2012) }\end{array}$ & $\begin{array}{l}\text { Identifying six underlying principles of } \\
\text { frugal innovation }\end{array}$ & $\begin{array}{l}\text { - Principles: robustness, portability, de-featuring, leapfrog } \\
\text { technology, mega-scale production, and service ecosystems. }\end{array}$ \\
\hline & $\begin{array}{l}\text { Radjou and } \\
\text { Prabhu } \\
\text { (2014) }\end{array}$ & $\begin{array}{l}\text { Identifying six underlying principles of } \\
\text { frugal innovation }\end{array}$ & $\begin{array}{l}\text { - Principles: engage and iterate, flex your assets, create } \\
\text { sustainable solutions, shape customer behaviour, co-create } \\
\text { value with prosumers, and make innovative friends. }\end{array}$ \\
\hline & $\begin{array}{l}\text { Prahalad and } \\
\text { Mashelkar } \\
\text { (2010) }\end{array}$ & $\begin{array}{l}\text { Introducing three Gandhian innovation } \\
\text { types (in our context, interpreted as } \\
\text { frugal innovation) } \\
\text { Introducing rules for Gandhian } \\
\text { innovation }\end{array}$ & $\begin{array}{l}\text { - The three Gandhian innovation types are as follows: disrupting } \\
\text { business models, modifying organisational capabilities, and } \\
\text { creating or sourcing new capabilities. } \\
\text { - The five rules for Gandhian innovation are as follows: } \\
\text { 1. Develop a deep commitment to serving the unserved. } \\
\text { 2. Articulate and embrace a clear vision. } \\
\text { 3. Set very ambitious goals to foster an entrepreneurial spirit. } \\
\text { 4. Accept that constraints will always exist and creatively } \\
\text { operate within them. } \\
\text { 5. Focus on people, not just shareholder wealth and profits. }\end{array}$ \\
\hline
\end{tabular}

in contrast to desirability and design. The last characteristic, location, is developing and emerging markets, in contrast to developed markets of conventional innovation.

Further publications create an understanding of frugal innovation by examining principles that underlie frugal innovation and frugal engineering. Kumar and Puranam (2012) identify six principles: robustness, portability, de-featuring, leapfrog technology, megascale production, and service ecosystems. Radjou and
Prabhu (2014) also present six principles: engage and iterate, flex your assets, create sustainable solutions, shape customer behaviour, co-create value with prosumers, and make innovative friends. Further principles and needed competencies to develop frugal and related innovations are discussed in the literature (Basu et al. 2013; Prahalad and Mashelkar 2010).

The abovementioned concepts, frameworks, and principles are helpful for us to get a better idea of what frugal 
innovation means. Prabhu and Gupta (2014) argue that "frugal innovations in products are easily identified by expert examination". However, it still seems difficult for us to determine what a frugal innovation is. In these concepts, frugal innovation is often related to developing and emerging markets, although frugal innovations have entered developed markets (Govindarajan and Trimble 2012; Immelt et al. 2009; von Zedtwitz et al. 2015). Accordingly, criteria to determine frugal innovation should be universal and should be independent from the question whether or not it is discussed in the context of emerging or developed markets. Further, the abovementioned distinguishing characteristics mainly focus on special aspects such as technical novelty, market novelty, or the field of scarcity. Using the scarcity field or market novelty and technical novelty for distinction are useful to point out particular differences between frugal innovation and other innovation types. However, by using the distinguishing characteristics depicted in Table 1, it remains difficult to clearly define frugal innovation in ways that, first, make it easier to determine whether or not an innovation is frugal and, second, what can be considered the most important aspects in order to develop frugal innovation.

In the literature, frugal innovation is seen as an outcome and as a process. Soni and Krishnan (2014) note that the process is often referred to as frugal engineering, with frugal innovation being the outcome. Brem and Wolfram (2014) have a similar understanding. In contrast, Basu et al. (2013) call the process frugal innovation-similar to George et al. (2012), who consider frugal innovation to be a complex process rather than only an outcome. We focus on attributes and descriptions of product innovation and service innovation rather than on processes. However, in our view, our results can also be transferred to processes.

\section{Methods}

Our approach is a multimethod approach based on the following four-step procedure: literature review, interaction with practitioners, category building, and deduction of criteria for frugal innovation.

First, we conducted a literature review to capture what is denoted by frugal innovation. We searched two databases, EBSCO Business Source Premier and ISI Web of Science, for relevant articles in the frugal innovation field. We conducted a key phrase search. As shown in the theory, the literature uses the terms frugal engineering and frugal innovation to treat similar issues. Thus, we used the key phrases "frugal innovation", "frugal innovations", and "frugal engineering" in the topic or abstract fields.

Our research included publications until October 2014. We found 36 results in EBSCO and 43 in ISI Web of Science. Since 17 articles were redundant, the total number of articles was 62 . We searched the articles for definitions and characteristics attributed to frugal innovation. Of these, 34 provided the searched information and we sorted out 28. We subsumed expressions of similar attributes, characteristics, and descriptions into categories in a first-cycle coding (Saldaña 2013; Miles et al. 2014). The results of the coding were reviewed by three researchers, of whom one has been an expert in the frugal innovation field for 5 years, one a sustainable product development expert for 2 years, and one an expert in collaborative product development for 3 years. None of these three researchers were involved in writing the paper. The results of the literature review and the coding were used to develop a questionnaire.

Second, we interviewed 45 managers from companies and researchers from different research institutes with intersections with frugal innovation per questionnaire. Since the interviews were part of a more extensive data collection series on frugal innovation, we used further methods, such as focus group interviews. The interviewees were asked which attributes identified in the first-cycle coding of the literature review apply to frugal innovation. We used a five-point rating scale (Sekaran and Bougie 2013). (Possible answers were fully applies, applies, neutral, applies to a lesser extent, and does not apply.) We provided an open field for comments. To define criteria for frugal innovation that are also valid for developed markets, we were particularly interested in managers from developed markets who were familiar with global and frugal innovation. To identify interviewees, we chose to contact participants of the symposium Frugal Innovation and the Internationalisation of $\mathrm{R} \& \mathrm{D}$ organised by the Hamburg University of Technology's Centre of Frugal Innovation in October 2014, as well as managers from companies doing frugal innovation. To ensure high familiarity with the term frugal innovation, interviewees had to meet frugal innovation experience-related criteria. We analysed the data and carefully checked that interviewees had been familiar with frugal innovation for more than a year and that the companies and the research institutes in question were involved in research or sales in the frugal innovation field. In the end, we could include the results of 34 interviews into our analysis.

Third, after analysing the results, we did a secondcycle coding in order to identify primary categories that subsume all characteristics attributed to frugal innovation. Fourth, on the basis of the identified primary categories, we developed criteria for frugal innovation and defined them in detail.

\section{Results}

\section{Literature review}

In the 62 identified articles, we searched for characterisations, definitions, and attributes used to describe frugal innovation. We were particularly interested in how frugal innovation was understood 
in each article. In some cases, only a few attributes were mentioned or the meaning had to be interpreted from the context. When the meaning was too blurred, we sorted the article out. In the end, we incorporated 86 items for attributes and characteristics used in 34 articles, as summarised in the second column of Table 2.

In step two, we conducted first-cycle coding, which is used to summarise segments of data (Saldaña 2013; Miles et al. 2014). We coded expressions of similar attributes, characteristics, or description by using attribute categories. We conducted inductive coding, meaning we developed codes progressively during data collection (Miles et al. 2014). As a result of the coding, nine attribute categories could be identified: functional and focussed on essentials, considerably lower initial cost or purchase price, reducing the total cost of ownership, minimising the use of material and financial resources, user-friendly and easy to use, robust, high value and quality, scalable and sales of large numbers, and sustainable (see column 1, Table 2). Table 3 in the Appendix provides a more detailed overview. To assure that the data are interpretable in a similar way, we checked for inter-rater reliability. We calculated Krippendorff's $\alpha$ on the basis of the coding of a second independent researcher. Krippendorff's $\alpha$ turned out to be $\alpha=.972$. Since it is customary to require $\alpha \geq .800$, our results are reliable (Gwet 2014; Krippendorff 2004).

\section{Interviews}

The nine attribute categories created in the first-cycle coding were used for the questionnaires of the interviews with the 45 managers and researchers. After data cleaning, we included answers of 34 interviewees into our analysis. Of these, 27 interviewees were managers from companies located in Germany or with subsidiaries there. The companies were from all branches and operated globally: 24 companies operated in Europe, 20 in Asia, 19 in North America, 17 in South America, 17 in Africa, 17 in the Commonwealth of Independent States, 16 in the Middle East, and 16 in Australia and Oceania. Of the interviewees, 22 were managers of larger multinational companies with more than 500 employees and annual turnover of at least 500 million euro. Of the interviewees, 18 were in executive position, 15 worked in $R \& D$, and seven were researchers from research institutes such as universities and research organisations located in Germany. Interviewees were asked which attributes apply to frugal innovation. The interview results indicate at least two attribute categories that are crucial for understanding frugal innovation: frugal innovation is "functional and focussed on essentials", according to all interviewees, and has "considerably lower initial cost or purchase price" according to 32 of the 34 interviewees. Further attributes identified in the literature review are also strongly associated with frugal innovation. "Reducing the total cost of ownership" is a distinctive attribute according to 27 interviewees,

Table 2 Attributes and characterisations of frugal innovation

\begin{tabular}{ll}
\hline Attribute categories (first-cycle coding) & Attributes and characterisations of frugal innovations used in articles ${ }^{\mathrm{a}}$ \\
\hline Functional and focussed on essentials & $\begin{array}{l}\text { Bare essentials, core benefits, cut corners, taking exception to some of the requirements, de-featuring, elim- } \\
\text { inating unessential functions, entirely new applications, provide the essential functions people need, fulfil } \\
\text { the requirements of awareness, fulfil the requirements of availability, good enough, light, limited features, } \\
\text { new functionality, do not have sophisticated technological features, portability, reduced functionalities, redu- } \\
\text { cing the complexity, tailor made, unnecessary frills stripped out }\end{array}$
\end{tabular}

Considerably lower initial cost or purchase price

Reducing the total cost of ownership

Minimising the use of material and financial resources

User-friendly and easy to use

Robust

High value and quality

Scalable and sales of large numbers

Sustainable
Accessible, affordable, affordability, avoid needless costs in the first place, cheaper, cost discipline, cost effective, extreme cost advantage, fulfil the requirements of access, fulfil the requirements of affordability, low budget, low cost, low prices, low priced, minimising non-essential costs, minimum cost, more affordable prices, much lower price, reducing cost, trying to reduce the cost, significantly lower costs, ultra-low cost

Reducing the cost of ownership

Avoiding obesity, draw sparingly on raw materials, economical means, economic use of resources, low input of resources, minimise the use of extensive resources, minimise the use of financial resources, minimise the use of material, reduces material use, reducing the use of scarce resources, resource-saving product

Easy to use, simple, simpler

Durable, low maintenance, reliable, robust, robustness, stable, sturdy, tough

Fulfilling or even exceeding certain pre-defined criteria of acceptable quality standards, good service, highend technology, high value, leapfrog technology, maintain quality, maximising value, right value proposition, value for money, value products

Drive profits through volumes, highly scalable, mega-scale production, scalable

Eco-friendly, ecological, little environmental intervention, low carbon footprint, meets green marketing objectives, service ecosystem, sustainability

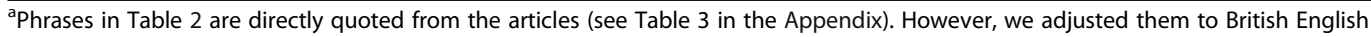


"minimising the use of material and financial resources" according to 25, "user-friendly and easy to use" as well as "robust" according to 24 , and "high value and quality" according to 23 , which corresponds to $68 \%$ of the interviewees. However, frugal innovation has the attribute "scalable and sales of large amounts" according to only 17 interviewees and is "sustainable" according to only 11 interviewees. The results are summarised in Fig. 1.

In the open field, one interviewee added "fulfilling local needs in terms of price and function" as an attribute of frugal innovation; another added "innovative design". Both attributes can be subsumed into the attribute categories "functional and focussed on essentials" and, in the first case, into "considerably lower cost or purchase price".

Most articles discussed in the literature review focus only on some attributes (see Table 3 in the Appendix), whereas the interviewees confirmed almost all attribute categories we had identified in the literature review. Only the attributes "scalable and sales of large amounts" and "sustainable" are confirmed as attributes of frugal innovation by a smaller number of interviewees; we discuss this later.

\section{Identification of primary categories}

To better understand what constitutes the core of frugal innovation, we conducted pattern coding as a secondcycle method to group the results of the first-cycle coding into a smaller number of categories (Saldaña 2013; Miles et al. 2014). We sought to identify primary categories on the basis of the attribute categories. The primary categories cost reduction, core functionality, and performance level could subsume the attribute categories (see Fig. 2).

To go into detail: we identified nine attribute categories. The first category is "functional and focussed on essentials" and was confirmed by $100 \%$ of the interviewees as a distinct attribute of frugal innovation. The attribute category "functional and focussed on essentials" could be subsumed to the primary category core functionality. The second and third attribute categories we identified are "considerably lower initial cost or purchase price" and "reducing the total ownership"; both can be subsumed into the primary category cost reduction. "Minimising the use of material and financial resources" could be matched to the primary categories cost reduction, core functionality, and performance level. The attribute category "user-friendly and easy to use" could be matched to the primary categories core functionality and performance level. "Robust" and "high value and quality" could be subsumed into the primary category performance level. We subsumed the attribute categories "scalable and sales of large numbers" and "sustainable" into "further issues". In the "Discussion" section, we explain why a further main category did not need to be created for these two aspects.

\section{Discussion}

The findings indicate that the discourse about frugal innovation mostly occur within the three main categories cost reduction, functionality, and performance level. Thus, most characteristics that are attributed to frugal innovation can be related to at least one of the three primary categories. Using the three categories, we defined criteria for frugal innovation.

The primary category, cost reduction, includes aspects such as "considerably lower initial cost or purchase price", "reducing the total cost of ownership", and "minimising the use of material and financial resources" (see Fig. 2). Attributes in the literature such as "much lower price", "significantly lower costs", or "ultra-low cost" (see Table 2) indicate significantly lower cost or prices. Thus, our first criterion for frugal innovation is "substantial cost reduction"; we define it in detail in the next section.

The second primary category, core functionality, contains aspects such as "functional and focussed on

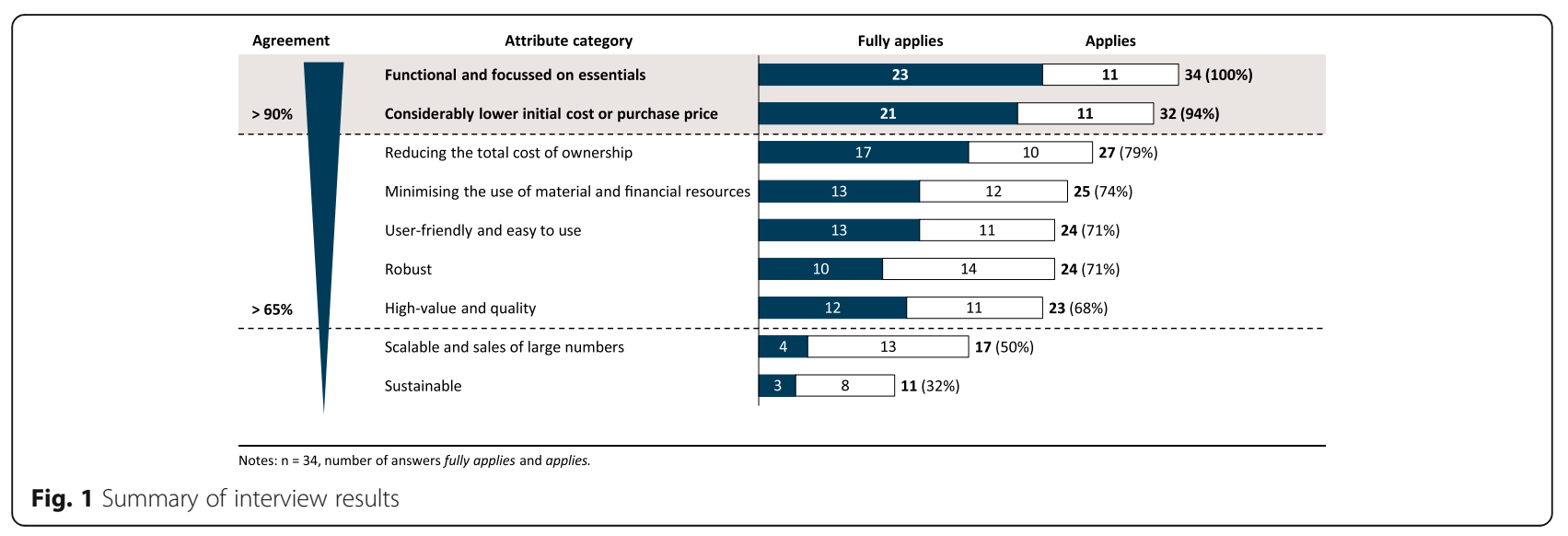




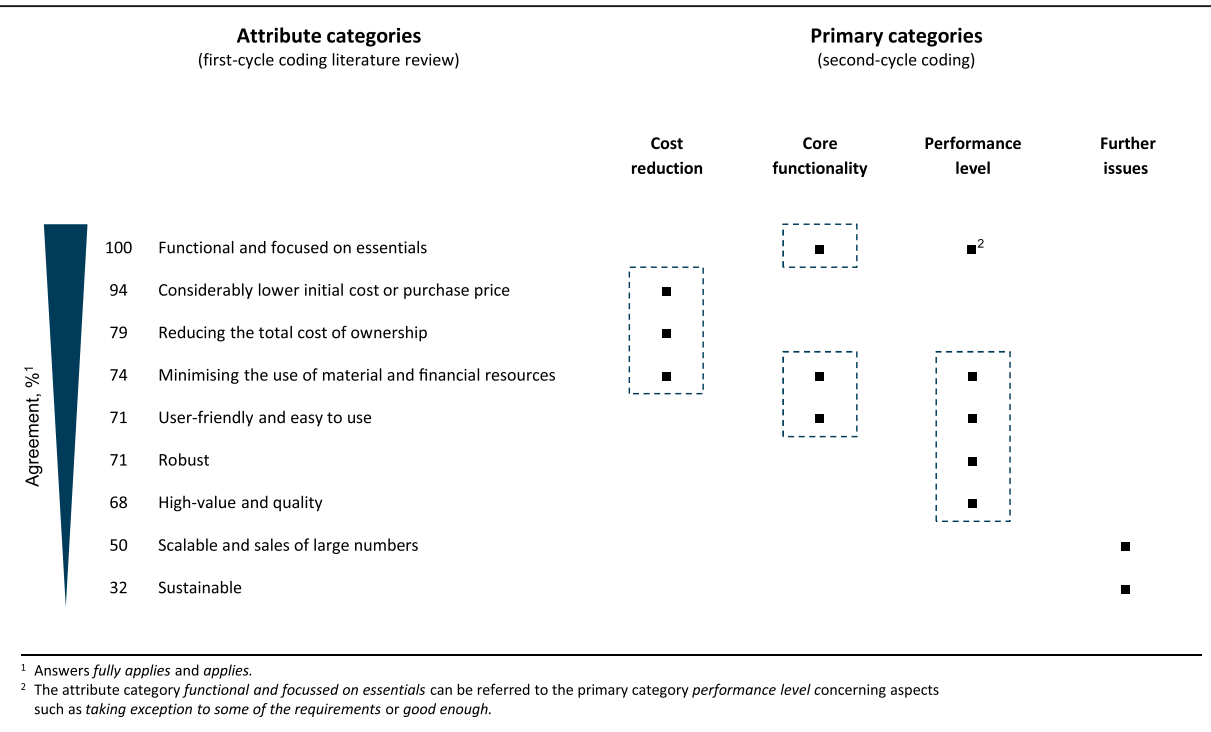

Fig. 2 Identification of the primary categories of frugal innovation

essentials", "minimising the use of material and financial resources", and "user-friendly and easy to use" (see Fig. 2). In the literature, this incorporates attributes and descriptions like "core benefits", "reduced functionalities", or "essential functions people need" (see Table 2). Thus, the second criterion for frugal innovation is concentration on core functionalities; we will define it in detail.

The third primary category is performance level. We could subsume many attributes describing frugal innovation into this category. For instance, frugal innovation is characterised as "easy to use", "reliable", "robust", "high-end technology", "maintain quality", or "fulfilling or even exceeding certain predefined criteria of acceptable quality standards" (see Table 2). At the same time, frugal innovation must meet very specific needs often not addressed by mature-market products (Sehgal et al. 2010). Therefore, our third criterion for frugal innovation is optimised performance level; we will define it in detail.

What all frugal innovations have in common is that they meet all three criteria simultaneously (see Fig. 3). However, how the three criteria we defined manifest in real products and services strongly depends on the user environment and context. For instance, while criterion 2, concentration on core functionalities, is valid for emerging markets and developed markets, the core functionalities will differ depending on the context.

The three criteria can also be relevant for other innovation types. Cost innovation also seeks significant cost reduction (Williamson 2010), and other innovation types also seek core functionality and simplicity (Flatters and Willmott 2009). The difference between frugal innovation and other innovation types is that frugal innovation must meet all of the three criteria at the same time.

\section{Substantial cost reduction}

Criterion 1 for frugal innovation is substantial cost reduction. Frugal innovation is characterised by a much lower price or significantly lower costs compared to conventional products and services. Almost every definition or description of frugal innovation in the literature emphasises this aspect, as we have seen in both the literature review and the interview results.

In the literature, it is not explicitly mentioned whether or not lower costs must always be from a customer perspective or whether or not an innovation can be frugal when there is a cost reduction only from a manufacturer or service provider perspective. By interpreting the findings, it becomes clear that it must always be from a customer perspective. As we have seen in the literature review, most characterisations are from a customer perspective, such as "affordable" (Jha and Krishnan 2013; Mukerjee 2012; Sharma and Iyer 2012; The Economist 2010), "low budget", or "low priced" (see Table 3 in the Appendix). A cost reduction that relates only to a manufacturer or service provider is insufficient, because it is not in line with most terms that characterise frugal innovation. Thus, the criterion substantial cost reduction must always be met from a customer perspective. This already includes the perspective of the manufacturer or service provider. 


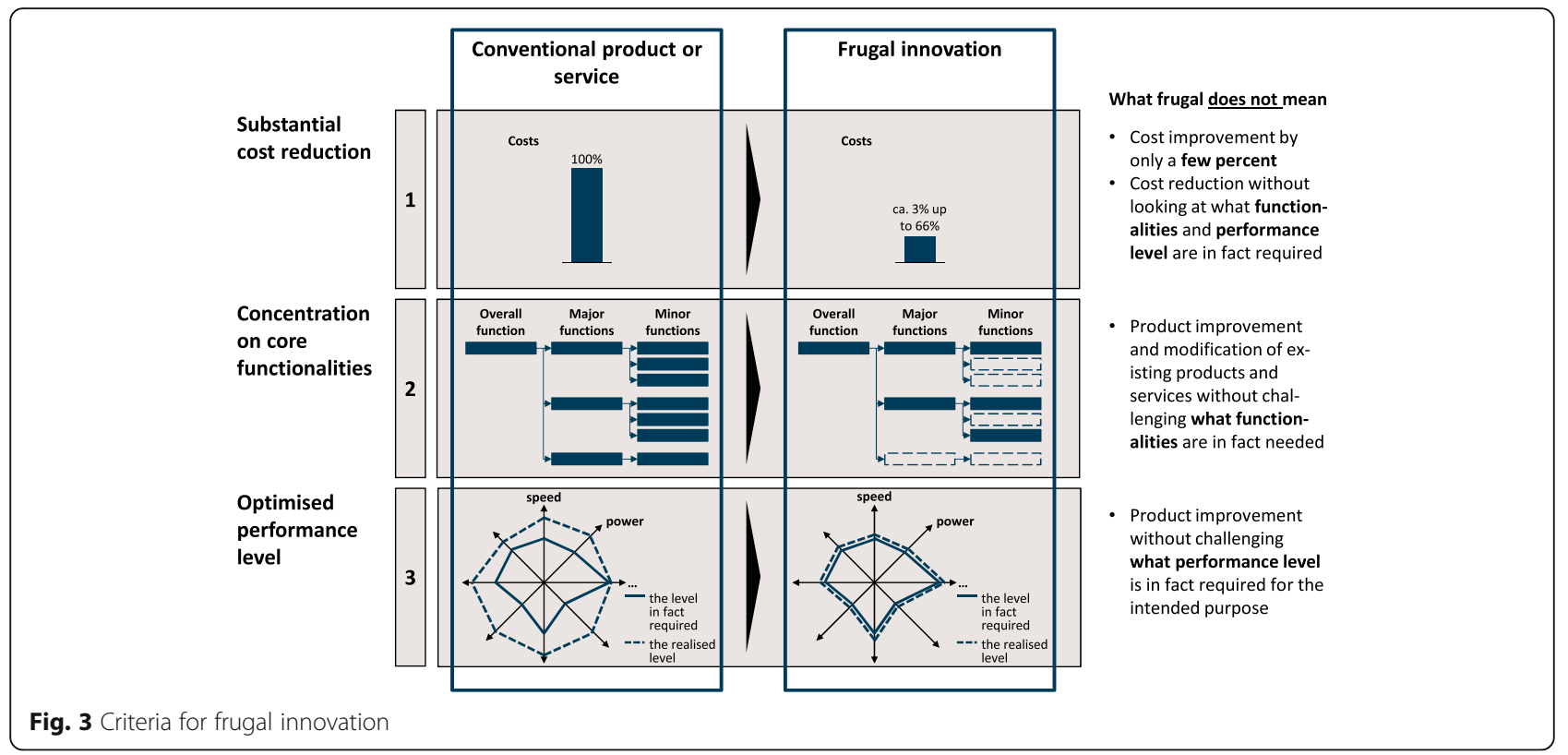

Few articles emphasise that frugal innovation seeks to reduce the total cost of ownership (Barclay 2014; Tiwari and Herstatt 2012). For Ojha (2014), this is at least valid for the Indian market (Ojha 2014). The criterion substantial cost reduction is in line with this perception and encompasses both lower cost or purchase price and reduced total cost of ownership. At least one of the two aspects must be met.

It is difficult to specify the extent of the cost reduction in frugal innovation. This question is not sufficiently answered in the literature. As we have seen in the literature review, characterisations such as "minimum cost", "much lower price", "significantly lower costs" or "ultra-low cost" indicate that the cost reduction must be significant for an innovation to be considered a frugal innovation. It is hard to determine a specific threshold value for the criterion substantial cost reduction, since there are no representative samples. Rao (2013) compared the prices of 13 frugal innovations with ordinary products and services, mainly based on Internet searches. On the basis of his comparison, the extent of cost reduction can be calculated and between 58 and $97 \%$ on an average of $80 \%$. Rao's understanding of frugal innovation here is mostly in line with our criteria, despite his short definition of "scarcity-induced-, minimalist- or reverse-innovation" (Rao 2013). While Rao's (2013) sample is not representative and quite small, it gives an indication of the extent of cost reduction. As long as no representative publications are available, we propose that frugal innovation's substantial cost reduction must be at least one third of comparable products but strongly depends on the user context.

Concerning criterion 1, frugal innovations have a significantly lower purchase price or lower total cost of ownership from a customer perspective (one third or more, with prices and costs compared to current solutions available on the market or, if no solution exists yet, with the assumed costs of making them available to the market, for instance by importing current solutions).

\section{Concentration on core functionalities}

Criterion 2 for frugal innovation is concentration on core functionalities. In the literature, frugal innovation is often associated with core benefits, essential functions, and reduced complexity (see Table 2 and Table 3 in the Appendix). Thus, the meaning of frugal innovation implies a focus on the core functionalities with the highest customer benefits, and it directly targets user requirements, as we will discuss in some detail: Wooldridge (2010, p. 3) notes that, "[i]nstead of adding ever more bells and whistles, they strip the products down to their bare essentials". Cunha et al. (2014, p. 202) point out that "frugal innovation aims to respond with extreme efficiency to some essential need". According to all the interviewees, frugal innovations are "functional and focussed on essentials", and most interviewees confirmed that frugal innovations "minimising the use of material and financial resources" and are "user-friendly and easy to use" (see Fig. 2). The criterion concentration on core functionalities is not 
only a way to reduce costs. Concentrating on core functionalities can also have the purpose of making a product or service easy to use (Andel 2013; Wooldridge 2010), of saving resources (Barclay 2014; Rao 2014; Tiwari and Herstatt 2012), of having a lower impact on the environment (Basu et al. 2013; Jänicke 2014; Sharma and Iyer 2012), or of meeting a specific lifestyle or consumer behaviour (Flatters and Willmott 2009). Thus, the criterion concentration on core functionalities encompasses all the aforementioned characterisations and is a discrete criterion.

In short, frugal innovations must concentrate on core functionalities compared to current solutions available in the market.

\section{Optimised performance level}

Criterion 3, optimised performance level, is particularly important if one is to capture the full meaning of frugal innovation. It is not sufficient to focus only on core functionalities. There must also be a serious examination of which levels of performance and quality are in fact required. Here, performance has a very broad meaning, covering the performance of all functionalities and engineering characteristics, such as speed, power, durability, and accuracy (see Fig. 3). The relevant engineering characteristics for which the performance level must be determined vary with the context. For instance, a frugal car has different engineering characteristics to a frugal ultrasound machine. Other innovation types also require serious examination of the performance level, not only frugal innovations. However, often, not all innovation types meet the criterion optimised performance level, especially by product innovations from developed markets, which are often over-engineered (one example is provided by Oliver Wyman (2013) that shows that Western manufacturers' premium and high-priced construction equipment do not meet the requirements of the global construction equipment market, with its growing demand for machines with technically simple and robust technologies that allow for do-ityourself repairs). Which performance level should be aimed for often receives insufficient attention. Literature characterise frugal innovations as "high-value, low-cost" and "high-end, low-cost technology products" (Ahuja 2014; Brem and Wolfram 2014; Ojha 2014), while Andel (2013, p. 4) describes the performance level of frugal innovations as "get the performance its engineers originally planned". This implies that the right level of performance and quality has to be achieved. Soni and Krishnan (2014, p. 31) underline this aspect: "meeting the desired objective with a good-enough, economical means".
Further, Tiwari and Herstatt (2012, p. 98) note that frugal innovations are "fulfilling or even exceeding certain pre-defined criteria of acceptable quality standards". Thus, frugal innovation should meet the performance and quality levels that are in fact required and with minimal costs.

There are two reasons why the criterion is optimised performance level. First, in some cases, the conventional performance level is not good enough for frugal innovation. An example of this is car horns in Indian cars. Since car horns are used excessively in India, they must be able to withstand much greater strain than in developed markets and even more than in other emerging markets (Herstatt et al. 2008). Thus, a higher performance level than that for horns in most premium cars in Europe is needed. This demonstrates that the performance level in frugal innovation is not always lower, to avoid over-engineering; in some cases, the requirement can be higher, as this example shows. The performance level must optimally fit the intended purpose and the specific requirements of the environment in which the frugal innovation will be used, especially for emerging and developing markets, with their special needs, but even for developed markets. The second reason is that the required level must be met very precisely. If the performance level is too high, as it is with the premium Western construction equipment, costs are too high. As noted, to significantly reduce costs is a primary aspect of frugal innovation. If the performance level is too low, specific requirements are not met and frugal innovation's aspiration to deliver "high value", "maintain quality", and "maximising value to the customer" (see Table 2 and Table 3 in the Appendix) is not met. Thus, an optimal performance level is crucial.

However, some frugal innovations use standard components or commercially available subsystems. GE Healthcare, a subsidiary of General Electric, developed a frugal electrocardiogram device, the MAC 400 , that contained a commonly used printer system, like those used for bus ticketing systems, to reduce costs (Ramdorai and Herstatt 2015). We argue, if it is cheaper to use a standard component or an already existing solution to develop a frugal innovation, it should be used, even if it might provide better than required performance. However, it is crucial to be aware of the optimal performance level before choosing a solution.

In short, frugal innovations must meet the performance level that is needed for its de facto purpose and the local conditions, compared to current solutions available in the market. 


\section{Possible additional characteristics}

In the literature review, frugal innovation is often characterised by attributes such as "highly scalable" or "drives profits through volumes", which we coded into the attribute category "scalable and sales of large numbers". We identified further attributes, such as "eco-friendly", "little environmental intervention", and "meets green marketing objectives", which we coded into the attribute category "sustainable" (see Table 2 and Table 3 in the Appendix). The interview results show that only 17 interviewees think frugal innovation can be characterised as scalable and only 11 think it can be characterised as sustainable (see Fig. 2). This indicates that frugal innovation does not necessarily involve scalability and sustainability. Frugal innovations can contribute to sustainability by minimising resource use (Jänicke 2014; Sharma and Iyer 2012). However, we assume that being sustainable often is not the primary focus. For instance, frugal innovations such as the Vscan ultrasound device (Govindarajan and Trimble 2012) for the Chinese market or the mini-truck Tata Ace (Tiwari and Herstatt 2014) for the Indian market were invented to meet local needs rather than to meet green marketing objectives. Scalability is also often mentioned as an attribute of frugal innovations (see Table 2 and Table 3 in the Appendix). The much lower prices for frugal products and services cause lower margins. Thus, more products or services must be sold compared to conventional innovation with higher margins to gain the same profit. This makes scalability important to frugal innovations. However, this criterion does not distinguish frugal innovations from non-frugal ones. We argue that frugal innovations can be also developed for small target groups as long as they generate profit.

Thus, frugal innovations can have additional characteristics such as being sustainable or scalable, but they are already frugal if they simultaneously meet the three criteria substantial cost reduction, concentration on core functionalities, and optimised performance level.

\section{Using the three criteria}

We will now illustrate how frugal innovation can take place by means of these criteria. The criteria are appropriate for all frugal innovation types and targeted at emerging and developed markets. For this reason, we chose two well-known examples: the MittiCool, a fridge made from clay (Radjou et al. 2012) which targets the emerging market in India, and the GE Vscan, a handheld, cellphone-sized ultrasound machine which was originally developed for the Chinese market and then also entered developed markets (Govindarajan and Trimble
2012). The procedure to determine whether or not an innovation can be considered frugal is to prove each of the three criteria.

The MittiCool particularly targets areas without electricity in India (Radjou et al. 2012). It was launched at a price of Rs2,500 (around 30 euro) (FT Foundation 2010). Fridges of the same size still cost at least Rs6,000 (around 80 euro), as per the website of the e-commerce company Flipkart (www.flipkart.com). Accordingly, in that market, the MittiCool costs almost $60 \%$ less than a comparable fridge. Thus, it meets criterion 1 (substantial cost reduction). The MittiCool is intended to cooling primarily water, fruits, vegetables, and dairy. Cooling is via water evaporation, fitting the local conditions without electricity. It has no further frills or functions such as lightning, different freezing levels or a freezing compartment. Thus, it also meets criterion 2 (concentration on core functionalities). The temperature is in the 5 to $8{ }^{\circ} \mathrm{C}$ (FT Foundation 2010), enough for its primary purposes. Its size $(18.5 \times 11$ in. $)$ is small but also big enough for its purposes. There is no need for higher or lower performance. Thus, it also meets criterion 3 (optimised performance level). Therefore, the MittiCool is a frugal innovation (see Fig. 4).

Our second example is the Vscan. The Vscan was developed for the Chinese market; in contrast with the MittiCool, it also targets developed markets, in which it is used for quick diagnosis (Govindarajan and Trimble 2012). The procedure to determine whether or not the Vscan is a frugal innovation is the same. It must be proven that all three criteria are met. As depicted in Fig. 4, the result is that the Vscan can also be characterised as a frugal innovation. This example illustrates that the three criteria are also appropriate for developed markets.

To illustrate a negative example: in developed markets, tablet computers vary greatly in prices. The cheapest cost about 100 euro, and the most expensive ones about 3000 euro (as per online retailers' websites). The cheap ones are much cheaper than the mid-priced or most expensive ones. Thus, criterion 1 is met. When seeking to prove criterion 2, it becomes apparent that the cheap tablets' number and types of functions seem very similar to the more expensive one, although their performance is lower. Often, they even use the same operating system. We cannot observe a focus on core functionalities. Thus, criterion 2 is not met. Now, criterion 3 must be proved. Compared to the more expensive tablets, the cheap ones have lower performance, such as a lower-resolution display, less storage space, or a slower processor. However, their performance levels are not optimised 


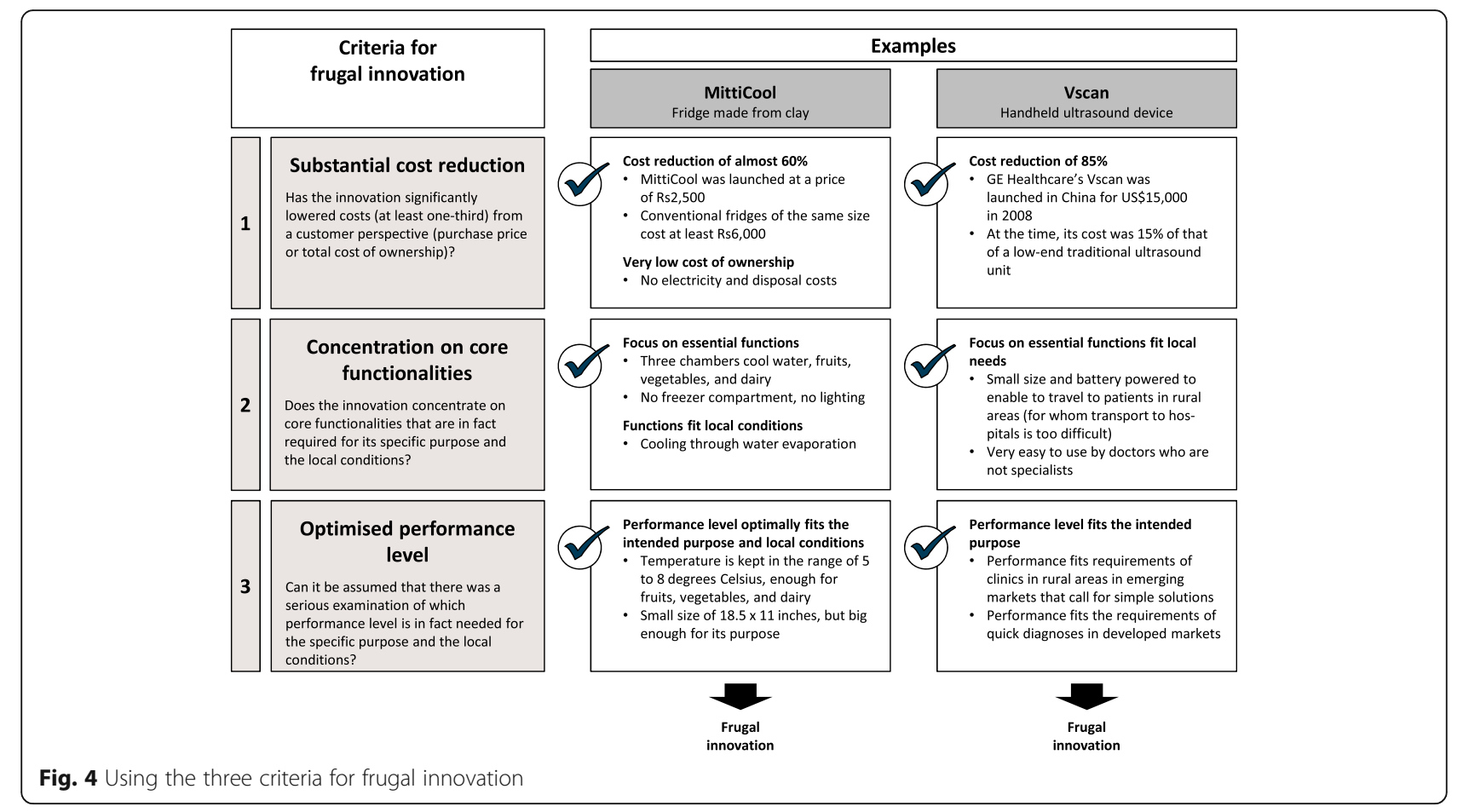

to a specific purpose, in contrast for instance to the laptops of the One Laptop per Child Association, which meet criterion 3 by optimising the performance of its robust and low-cost laptops for self-empowered learning of the world's poorest children (OLPC Association 2015). In our example, criterion 3 is not met. We conclude that cheap tablets sold in developed markets are not frugal innovations. Although criterion 1 is met owing to much lower prices, criteria 2 and 3 are not. Thus, cheap tablets in developed markets are simply cost innovations.

\section{Contribution, limitations, and further research}

Our examination of frugal innovation and our three criteria for frugal innovation have several implications.

\section{Theoretical implications}

We contribute to the literature on frugal innovation in two primary ways. First, we refined the meaning of frugal innovation and its basic concept. Previous definitions often relied on specific attributes. However, attributes of frugal innovation can differ. Frugal innovation for emerging markets with specific conditions concerning infrastructure, climate, or customer habits must fulfil different requirements compared to frugal innovation for developed markets. Even in emerging markets, attributes such as robustness or the ability to deal with frequent blackouts can be important for some markets, but not for others. Thus, the three criteria are defined independently of specific attributes or target markets. How the three criteria manifest in real products and services strongly depends on the user environment and the context. However, we recommend that one refers to an innovation as frugal if all three criteria-substantial cost reduction, concentration on core functionalities, and optimised performance level-are met simultaneously.

Second, we advance the understanding of frugal innovation. As noted, frugal innovation meets all three criteria at the same time. This can be helpful to better understand why it can be challenging to develop frugal innovations. First principles and approaches to develop frugal innovation have been published (Basu et al. 2013; Kumar and Puranam 2012; Lehner and Gausemeier 2016; Prahalad 2012; Prahalad and Mashelkar 2010; Radjou and Prabhu 2014). However, owing to the research stream's newness, we still lack a comprehensive theoretical understanding of frugal innovation (Cunha et al. 2014). Our three criteria provide a structure of the primary aspects that must be considered if one is to understand and to be able to develop frugal innovations.

\section{Managerial implications}

Two managerial implications result from the discussion. First, to develop frugal innovations, organisations must find out how a specific frugal innovation 
must look like. Attributes of frugal innovations can differ tremendously, as we saw in the literature review. The specific attributes of frugal innovations strongly depend on the specific context, such as the environment, the specific needs, or the market structure. Thus, instead of trying to find out what the key general attributes of frugal innovation are, to which there is no universal answer, organisations should use the three criteria as a framework to identify the specific attributes and characteristics required to meet customers' specific needs in a certain context and an intended purpose.

Second, to develop frugal innovations, organisations should consider all three criteria to identify all specific attributes and characteristics required to make a new product or service a frugal one. Since the development of frugal innovations involves meeting all three criteria simultaneously, each criterion must be considered.

\section{Limitations and further research}

Our study has limitations. First, the frugal innovation research stream is fairly new and is still evolving. The number of peer-reviewed publications in the frugal innovations field is small and is gradually increasing. To enhance this research field, it was necessary to include non-peer-reviewed articles and publications. Second, we had to decide which criteria we should use to select publications. Thus, we only included publications from the EBSCO Business Source Premier and ISI Web of Science databases. These databases did not capture all the articles in the frugal innovation field. Some wellknown publications are not part of the literature review because the key phrase search missed them (Cunha et al. 2014; Radjou and Prabhu 2014; Rao 2013; Tiwari and Herstatt 2014). Nonetheless, our literature review findings would be similar if these articles would have been included, owing to their similar understandings of frugal innovation. Third, interviewees were only from Germany. This might not provide a comprehensive picture of the worldwide understanding of frugal innovation. However, the interviewees were managers of companies that operate globally, notably in emerging markets, and are therefore familiar with the different requirements of developed and emerging markets. Further, we were particularly interested in the understanding of frugal innovation in developed markets; little is known in this regard. The results show that the interviewees' understandings broadly resemble the understanding in the literature. This indicates a similar perception of frugal innovation in emerging and developed markets. Fourth, the meaning of frugal innovation is still evolving. On the one hand, proposing criteria for frugal innovation might constrain the broadness of the current discussions. On the other hand, to agree on criteria that must be met to characterise a certain innovation type as frugal gave us the opportunity to help to consolidate the research stream.

Clearly, further research is needed. First, the three criteria for frugal innovation can be useful to consider the key aspects during the product development process. However, it is challenging to develop frugal innovations, especially for firms in developed markets. Researchers should explore how frugal innovations can be successfully developed. Second, we need to look at the challenges that can be encountered while pursuing frugal innovation. Third, to date, little is known about the potential of frugal products and services for developing markets. More research needs to be done if we are to better understand for which organisations and target groups frugal innovations hold promise.

\section{Conclusions}

The frugal innovation research stream is still new. Apperantly, the literature of fugal innovation has primarily focussed on emerging markets. However, currently, frugal innovations are also adapted for developed markets (Govindarajan and Trimble 2012; The Economist 2012). As a consequence, it is crucial to have a common understanding of the term frugal innovation. It would be useful to agree on certain criteria that must be met if one is to characterise an innovation as frugal.

With this objective in mind, we examined the meaning of frugal innovation. We identified that most attributes and characterisations of frugal innovations can be subsumed into three categories. On the basis of the identified categories, we defined three criteria for frugal innovation. We propose that innovations are frugal if they simultaneously meet the criteria substantial cost reduction, concentration on core functionalities, and optimised performance level.

It is clear that attributes and characteristics of frugal innovation depend on the target markets, which have different needs and local conditions. Thus, the attributes of frugal innovation can vary greatly. Our three criteria for frugal innovation illustrate the core concept independently of the target market or specific attributes. Therefore, these criteria can be used for both emerging and developed markets. We conclude that this results in a more profound understanding of the core of frugal innovation, to better meet the requirements of emerging markets and to transfer and adapt the main concept from emerging markets to developed markets. 


\section{Appendix}

Table 3 Categorisation of characterisations and attributes of frugal innovation

\begin{tabular}{|c|c|c|c|c|c|c|c|c|c|c|}
\hline \multirow[t]{2}{*}{ Article } & \multirow[t]{2}{*}{ Quotation $^{\mathrm{a}}$} & \multicolumn{9}{|c|}{ Attribute categories } \\
\hline & & $\begin{array}{l}\text { Functional } \\
\text { and } \\
\text { focussed } \\
\text { on } \\
\text { essentials }\end{array}$ & $\begin{array}{l}\text { Considerably } \\
\text { lower initial } \\
\text { cost or } \\
\text { purchase } \\
\text { price }\end{array}$ & $\begin{array}{l}\text { Reducing } \\
\text { the total } \\
\text { cost of } \\
\text { ownership }\end{array}$ & $\begin{array}{l}\text { Minimising } \\
\text { the use of } \\
\text { material } \\
\text { and } \\
\text { financial } \\
\text { resources }\end{array}$ & $\begin{array}{l}\text { User- } \\
\text { friendly } \\
\text { and } \\
\text { easy to } \\
\text { use }\end{array}$ & Robust & $\begin{array}{l}\text { High } \\
\text { value } \\
\text { and } \\
\text { quality }\end{array}$ & $\begin{array}{l}\text { Scalable } \\
\text { and } \\
\text { sales of } \\
\text { large } \\
\text { numbers }\end{array}$ & Sustainable \\
\hline $\begin{array}{l}\text { Agarwal } \\
\text { and Brem } \\
\text { (2012) }\end{array}$ & $\begin{array}{l}\text { "good-enough", "affordable" } \\
\text { (p. 2), "Frugal products with } \\
\text { heavy resource constraints } \\
\text { have extreme cost advantages } \\
\text { compared to existing } \\
\text { solutions and are much } \\
\text { simpler and cheaper with } \\
\text { limited features" (p. 2) }\end{array}$ & $\bullet$ & $\bullet$ & & & $\bullet$ & & & & \\
\hline $\begin{array}{l}\text { Ahuja } \\
\text { (2014) }\end{array}$ & $\begin{array}{l}\text { "cost that will make the } \\
\text { solution accessible to as many } \\
\text { individuals as possible" (p. 54), } \\
\text { "high-value, low-cost, and } \\
\text { scalable products" (p. 55), } \\
\text { "more efficient, cost-effective, } \\
\text { and eco-friendly" (p. 55) }\end{array}$ & & $\bullet$ & & & & & $\bullet$ & $\bullet$ & $\bullet$ \\
\hline $\begin{array}{l}\text { Andel } \\
\text { (2013) }\end{array}$ & $\begin{array}{l}\text { "keep it simple" (p. 4), "cut } \\
\text { corners, taking exception to } \\
\text { some of the requirements" } \\
\text { (p. 4) }\end{array}$ & $\bullet$ & & & & $\bullet$ & & & & \\
\hline $\begin{array}{l}\text { Barclay } \\
\text { (2014) }\end{array}$ & $\begin{array}{l}\text { "reducing the complexity and } \\
\text { cost" (p. 165), "reducing the } \\
\text { complexity and cost of a } \\
\text { good or service" (p. 172), } \\
\text { "good-enough", "affordable } \\
\text { products" (p. 172), "lean or } \\
\text { cost-effective" (p. 172), "seek } \\
\text { to minimize the use of } \\
\text { extensive resources in the } \\
\text { complete value chain with the } \\
\text { intent of reducing the cost of } \\
\text { ownership while fulfilling or } \\
\text { even exceeding certain } \\
\text { pre-defined criteria of } \\
\text { acceptable quality standards" } \\
\text { (p. 173) }\end{array}$ & $\bullet$ & $\bullet$ & $\bullet$ & $\bullet$ & & & $\bullet$ & & \\
\hline $\begin{array}{l}\text { Bills et al. } \\
\text { (2014) }\end{array}$ & "low-cost" (p. 3022) & & $\bullet$ & & & & & & & \\
\hline $\begin{array}{l}\text { Brem and } \\
\text { Wolfram } \\
\text { (2014) }\end{array}$ & $\begin{array}{l}\text { "do not have sophisticated } \\
\text { technological features", "low } \\
\text { cost", "comparably high value", } \\
\text { "simple and ecological } \\
\text { products, processes, services, } \\
\text { and business models", "low } \\
\text { input of resources", "low cost", } \\
\text { "little environmental } \\
\text { intervention", "low carbon } \\
\text { footprint", "core benefits", } \\
\text { "eliminating unessential } \\
\text { functions", "maintain quality", } \\
\text { "maximize value", "minimize } \\
\text { inessential costs" (p. 5) }\end{array}$ & $\bullet$ & $\bullet$ & & $\bullet$ & $\bullet$ & & $\bullet$ & & $\bullet$ \\
\hline Craig (2012) & $\begin{array}{l}\text { "product that can be afforded } \\
\text { by those at the bottom of the } \\
\text { bottom of the economic } \\
\text { pyramid", "reliable" (p. 36) }\end{array}$ & & $\bullet$ & & & & $\bullet$ & & & \\
\hline
\end{tabular}


Table 3 Categorisation of characterisations and attributes of frugal innovation (Continued)

\begin{tabular}{|c|c|c|c|c|c|c|c|c|c|c|}
\hline \multirow[t]{2}{*}{ Article } & \multirow[t]{2}{*}{ Quotation $^{a}$} & \multicolumn{9}{|c|}{ Attribute categories } \\
\hline & & $\begin{array}{l}\text { Functional } \\
\text { and } \\
\text { focussed } \\
\text { on } \\
\text { essentials }\end{array}$ & $\begin{array}{l}\text { Considerably } \\
\text { lower initial } \\
\text { cost or } \\
\text { purchase } \\
\text { price }\end{array}$ & $\begin{array}{l}\text { Reducing } \\
\text { the total } \\
\text { cost of } \\
\text { ownership }\end{array}$ & $\begin{array}{l}\text { Minimising } \\
\text { the use of } \\
\text { material } \\
\text { and } \\
\text { financial } \\
\text { resources }\end{array}$ & $\begin{array}{l}\text { User- } \\
\text { friendly } \\
\text { and } \\
\text { easy to } \\
\text { use }\end{array}$ & Robust & $\begin{array}{l}\text { High } \\
\text { value } \\
\text { and } \\
\text { quality }\end{array}$ & $\begin{array}{l}\text { Scalable } \\
\text { and } \\
\text { sales of } \\
\text { large } \\
\text { numbers }\end{array}$ & Sustainable \\
\hline $\begin{array}{l}\text { Dandonoli } \\
\text { (2013) }\end{array}$ & $\begin{array}{l}\text { "ultra-low cost, durable, easy } \\
\text { to use, draw sparingly on raw } \\
\text { materials and minimize } \\
\text { environmental impact", } \\
\text { "significantly lower costs" } \\
\text { (p. 2) }\end{array}$ & & $\bullet$ & & $\bullet$ & $\bullet$ & $\bullet$ & & & $\bullet$ \\
\hline $\begin{array}{l}\text { Fukuda and } \\
\text { Watanabe } \\
\text { (2011) }\end{array}$ & $\begin{array}{l}\text { "accessibility, accountability } \\
\text { and affordability" (p. 92) }\end{array}$ & & $\bullet$ & & & & & & & \\
\hline $\begin{array}{l}\text { Gupta and } \\
\text { Wang } \\
(2010)\end{array}$ & "sturdy", "stable" & & & & & & $\bullet$ & & & \\
\hline $\begin{array}{l}\text { Howard } \\
\text { (2011) }\end{array}$ & $\begin{array}{l}\text { "low-cost", "low carbon } \\
\text { footprint" (p. 53) }\end{array}$ & & $\bullet$ & & & & & & & $\bullet$ \\
\hline $\begin{array}{l}\text { Jha and } \\
\text { Krishnan } \\
\text { (2013) }\end{array}$ & $\begin{array}{l}\text { "low-priced, value products } \\
\text { that can drive profits through } \\
\text { volumes", "affordable, value } \\
\text { products that meet the needs } \\
\text { of resource-constrained } \\
\text { customers" (p. 250) }\end{array}$ & & $\bullet$ & & & & & $\bullet$ & $\bullet$ & \\
\hline $\begin{array}{l}\text { Kahle et al. } \\
\text { (2013) }\end{array}$ & $\begin{array}{l}\text { "low-cost", "offer high value", } \\
\text { "fulfil the requirements of } \\
\text { awareness, access, } \\
\text { affordability, and availability" } \\
\text { (p. 221) }\end{array}$ & $\bullet$ & $\bullet$ & & & & & $\bullet$ & & \\
\hline $\begin{array}{l}\text { Kumar } \\
\text { (2008) }\end{array}$ & "value for money" (p. 251) & & & & & & & $\bullet$ & & \\
\hline $\begin{array}{l}\text { Kumar and } \\
\text { Puranam } \\
\text { (2012) }\end{array}$ & $\begin{array}{l}\text { "robustness", "portability", } \\
\text { "defeaturing", "leapfrog } \\
\text { technology", "megascale } \\
\text { production", "service } \\
\text { ecosystem" }\end{array}$ & $\bullet$ & & & & & $\bullet$ & $\bullet$ & $\bullet$ & $\bullet$ \\
\hline $\begin{array}{l}\text { Leavy } \\
\text { (2014) }\end{array}$ & $\begin{array}{l}\text { "Affordability and } \\
\text { sustainability" (p. 36) }\end{array}$ & & $\bullet$ & & & & & & & $\bullet$ \\
\hline $\begin{array}{l}\text { Lim et al. } \\
\text { (2013) }\end{array}$ & $\begin{array}{l}\text { "resource-saving product for } \\
\text { low income consumers" } \\
\text { (p. 393) }\end{array}$ & & & & $\bullet$ & & & & & \\
\hline $\begin{array}{l}\text { Mandal } \\
\text { (2014) }\end{array}$ & $\begin{array}{l}\text { "low-cost solutions using } \\
\text { homegrown or self-created } \\
\text { technologies, often born out } \\
\text { of dire need" (p. 11) }\end{array}$ & & $\bullet$ & & & & & & & \\
\hline $\begin{array}{l}\text { Mukerjee } \\
(2012)\end{array}$ & $\begin{array}{l}\text { "tailor made", "right value } \\
\text { proposition", "affordability } \\
\text { becomes the key issue" }\end{array}$ & $\bullet$ & $\bullet$ & & & & & $\bullet$ & & \\
\hline $\begin{array}{l}\text { Nocera } \\
(2012)\end{array}$ & $\begin{array}{l}\text { "light and highly } \\
\text { manufacturable as well as } \\
\text { robust and low maintenance" } \\
\text { (p. 47) }\end{array}$ & & & & & & $\bullet$ & & & \\
\hline
\end{tabular}


Table 3 Categorisation of characterisations and attributes of frugal innovation (Continued)

\begin{tabular}{|c|c|c|c|c|c|c|c|c|c|c|}
\hline \multirow[t]{2}{*}{ Article } & \multirow[t]{2}{*}{ Quotation $^{a}$} & \multicolumn{9}{|c|}{ Attribute categories } \\
\hline & & $\begin{array}{l}\text { Functional } \\
\text { and } \\
\text { focussed } \\
\text { on } \\
\text { essentials }\end{array}$ & $\begin{array}{l}\text { Considerably } \\
\text { lower initial } \\
\text { cost or } \\
\text { purchase } \\
\text { price }\end{array}$ & $\begin{array}{l}\text { Reducing } \\
\text { the total } \\
\text { cost of } \\
\text { ownership }\end{array}$ & $\begin{array}{l}\text { Minimising } \\
\text { the use of } \\
\text { material } \\
\text { and } \\
\text { financial } \\
\text { resources }\end{array}$ & $\begin{array}{l}\text { User- } \\
\text { friendly } \\
\text { and } \\
\text { easy to } \\
\text { use }\end{array}$ & Robust & $\begin{array}{l}\text { High } \\
\text { value } \\
\text { and } \\
\text { quality }\end{array}$ & $\begin{array}{l}\text { Scalable } \\
\text { and } \\
\text { sales of } \\
\text { large } \\
\text { numbers }\end{array}$ & Sustainable \\
\hline Ojha (2014) & $\begin{array}{l}\text { "high-end low-cost technol- } \\
\text { ogy products for markets such } \\
\text { as India, which are demanding } \\
\text { in terms of features of the } \\
\text { products and/or services of- } \\
\text { fered but are also demanding } \\
\text { in terms of the price" (p. 8) }\end{array}$ & & $\bullet$ & & & & & $\bullet$ & & \\
\hline $\begin{array}{l}\text { Pawlowski } \\
\text { (2013) }\end{array}$ & $\begin{array}{l}\text { "Frugal innovation is about } \\
\text { creating highly scalable } \\
\text { products which have reduced } \\
\text { functionalities while reducing } \\
\text { costs" (p. 527) }\end{array}$ & $\bullet$ & $\bullet$ & & & & & & $\bullet$ & \\
\hline $\begin{array}{l}\text { Prabhu and } \\
\text { Gupta } \\
\text { (2014) }\end{array}$ & $\begin{array}{l}\text { "Frugal innovations in } \\
\text { products are vital in } \\
\text { developing countries to reach } \\
\text { price sensitive customers that } \\
\text { seek robust products at low } \\
\text { prices" (p. 3309) }\end{array}$ & & $\bullet$ & & & & $\bullet$ & & & \\
\hline $\begin{array}{l}\text { Radjou and } \\
\text { Prabhu } \\
\text { (2013) }\end{array}$ & $\begin{array}{l}\text { "ability to generate } \\
\text { considerably more business } \\
\text { and social value while } \\
\text { significantly reducing the use } \\
\text { of scarce resources" (p. 1) }\end{array}$ & & & & $\bullet$ & & & $\bullet$ & & \\
\hline Rao (2014) & $\begin{array}{l}\text { "low-budget" (p. 44), } \\
\text { "economic usage of } \\
\text { resources", "avoiding obesity" } \\
\text { (p. 45) }\end{array}$ & & $\bullet$ & & $\bullet$ & & & & & \\
\hline $\begin{array}{l}\text { Sehgal et al. } \\
\text { (2011) }\end{array}$ & $\begin{array}{l}\text { "Cost discipline is an intrinsic } \\
\text { part of the process but, rather } \\
\text { than simply cutting existing } \\
\text { costs, frugal engineering seeks } \\
\text { to avoid needless costs in the } \\
\text { first place" (p. 33), "maximising } \\
\text { value to the customer while } \\
\text { minimising non-essential } \\
\text { costs" (p. 35), "The ultimate } \\
\text { goal of frugal engineering is } \\
\text { basic: to provide the essential } \\
\text { functions people need" (p. 35) }\end{array}$ & $\bullet$ & $\bullet$ & & $\bullet$ & & & $\bullet$ & & \\
\hline $\begin{array}{l}\text { Sharma and } \\
\text { lyer (2012) }\end{array}$ & $\begin{array}{l}\text { "frugal engineering that } \\
\text { reduces material use (thereby } \\
\text { reducing burden on supply } \\
\text { chain) and meets green } \\
\text { marketing objectives at much } \\
\text { lower, and therefore, more } \\
\text { affordable prices" (p. 599) }\end{array}$ & & $\bullet$ & & $\bullet$ & & & & & $\bullet$ \\
\hline $\begin{array}{l}\text { Soni and } \\
\text { Krishnan } \\
\text { (2014) }\end{array}$ & $\begin{array}{l}\text { "meeting the desired } \\
\text { objective with a good- } \\
\text { enough, economical means" } \\
\text { (p. 31) }\end{array}$ & $\bullet$ & & & $\bullet$ & & & & & \\
\hline $\begin{array}{l}\text { The } \\
\text { Economist } \\
\text { (2012) }\end{array}$ & $\begin{array}{l}\text { "unnecessary frills stripped } \\
\text { out" }\end{array}$ & $\bullet$ & & & & & & & & \\
\hline
\end{tabular}


Table 3 Categorisation of characterisations and attributes of frugal innovation (Continued)

\begin{tabular}{|c|c|c|c|c|c|c|c|c|c|c|}
\hline \multirow[t]{2}{*}{ Article } & \multirow[t]{2}{*}{ Quotation $^{\mathrm{a}}$} & \multicolumn{9}{|c|}{ Attribute categories } \\
\hline & & $\begin{array}{l}\text { Functional } \\
\text { and } \\
\text { focussed } \\
\text { on } \\
\text { essentials }\end{array}$ & $\begin{array}{l}\text { Considerably } \\
\text { lower initial } \\
\text { cost or } \\
\text { purchase } \\
\text { price }\end{array}$ & $\begin{array}{l}\text { Reducing } \\
\text { the total } \\
\text { cost of } \\
\text { ownership }\end{array}$ & $\begin{array}{l}\text { Minimising } \\
\text { the use of } \\
\text { material } \\
\text { and } \\
\text { financial } \\
\text { resources }\end{array}$ & $\begin{array}{l}\text { User- } \\
\text { friendly } \\
\text { and } \\
\text { easy to } \\
\text { use }\end{array}$ & Robust & $\begin{array}{l}\text { High } \\
\text { value } \\
\text { and } \\
\text { quality }\end{array}$ & $\begin{array}{l}\text { Scalable } \\
\text { and } \\
\text { sales of } \\
\text { large } \\
\text { numbers }\end{array}$ & Sustainable \\
\hline $\begin{array}{l}\text { The } \\
\text { Economist } \\
\text { (2010) }\end{array}$ & $\begin{array}{l}\text { "trying to reduce the cost of } \\
\text { something in order to make it } \\
\text { affordable" }\end{array}$ & & $\bullet$ & & & & & & & \\
\hline $\begin{array}{l}\text { Tiwari and } \\
\text { Herstatt } \\
(2012)\end{array}$ & $\begin{array}{l}\text { "seek to minimize the use of } \\
\text { material and financial } \\
\text { resources in the complete } \\
\text { value chain (development, } \\
\text { manufacturing, distribution, } \\
\text { consumption, and disposal) } \\
\text { with the objective of reducing } \\
\text { the cost of ownership while } \\
\text { fulfilling or even exceeding } \\
\text { certain pre-defined criteria of } \\
\text { acceptable quality standards" } \\
\text { (p. 98) }\end{array}$ & & & $\bullet$ & $\bullet$ & & & $\bullet$ & & \\
\hline $\begin{array}{l}\text { Wooldridge } \\
\text { (2010) }\end{array}$ & $\begin{array}{l}\text { "Instead of adding ever more } \\
\text { bells and whistles, they strip } \\
\text { the products down to their } \\
\text { bare essentials", "Frugal } \\
\text { products need to be tough } \\
\text { and easy to use" (p. 3) }\end{array}$ & $\bullet$ & & & & $\bullet$ & $\bullet$ & & & \\
\hline $\begin{array}{l}\text { Zeschky et } \\
\text { al. (2011) }\end{array}$ & $\begin{array}{l}\text { "We have adopted the term } \\
\text { frugal innovation, defined as } \\
\text { responding to severe resource } \\
\text { constraints with products } \\
\text { having extreme cost } \\
\text { advantages compared to } \\
\text { existing solutions" (p. 39) }\end{array}$ & & $\bullet$ & & & & & & & \\
\hline $\begin{array}{l}\text { Zeschky et } \\
\text { al. (2014) }\end{array}$ & $\begin{array}{l}\text { "new functionality at a lower } \\
\text { cost" (p. 23), "entirely new } \\
\text { applications at much lower } \\
\text { price points than existing } \\
\text { solutions" (p. 23) }\end{array}$ & $\bullet$ & $\bullet$ & & & & & & & \\
\hline
\end{tabular}

${ }^{a}$ This column lists the attributes and characterisations of frugal innovation used in literature. If articles adopted them from other articles, we do not refer to the original source

\section{Authors' contributions}

All authors read and approved the final manuscript.

\section{Competing interests}

The authors declare that they have no competing interests.

Received: 27 May 2016 Accepted: 10 December 2016 Published online: 27 December 2016

\section{References}

Agarwal, N., \& Brem, A. (2012). Frugal and reverse innovation-literature overview and case study insights from a German MNC in India and China. In B. Katzy, T. Holzmann, K. Sailer, \& K. D. Thoben (Eds.), Proceedings of the 2012 18th International Conference on Engineering, Technology and Innovation (pp. 1-11).

Ahuja, S. (2014). Cost vs. value + empathy: a new formula for frugal science. Design Management Review, 25(2), 52-55.

Andel, T. (2013). Frugal price: virtue or vice? Material Handling \& Logistics, 68(11), 4. Barclay, C. (2014). Using frugal innovations to support cybercrime legislations in small developing states: introducing the cyber-legislation development and implementation process model (CyberLeg-DPM). Information Technology for Development, 20(2), 165-195.
Basu, R. R., Banerjee, P. M., \& Sweeny, E. G. (2013). Frugal innovation: core competencies to address global sustainability. Journal of Management for Global Sustainability, 1(2), 63-82.

Bhatti, Y. A., \& Ventresca, M. (2013). How can 'frugal innovation' be conceptualized? Said Business School Working Paper Series, Oxford.

Bills, T., Bryant, R., \& Bryant, A. W. (2014). Towards a frugal framework for monitoring road quality. In 17th International IEEE Conference on Intelligent Transportation Systems (ITSC).

Brem, A., \& Wolfram, P. (2014). Research and development from the bottom upintroduction of terminologies for new product development in emerging markets. Journal of Innovation and Entrepreneurship, 3(1), 1-22.

Craig, A. (2012). Back to basics. Supply Management, 17(1), 36-39.

Cunha, M. P. e., Rego, A., Oliveira, P., Rosado, P., \& Habib, N. (2014). Product innovation in resource-poor environments: three research streams. Journal of Product Innovation Management, 31(2), 202-210.

Dandonoli, P. (2013). Open innovation as a new paradigm for global collaborations in health. Global Health, 9(41), 1-5.

Flatters, P., \& Willmott, M. (2009). Understanding the post-recession consumer. Harvard Business Review, 87(7-8), 106-112.

FT Foundation. (2010). What a cool idea: a fridge that doesn't need electricity. Retrieved January 09, 2016, from http://www.ftfoundation.com/English/pdf/ Cool_Idea.pdf. 
Fukuda, K., \& Watanabe, C. (2011). A perspective on frugality in growing economies: triggering a virtuous cycle between consumption propensity and growth. Journal of Technology Management for Growing Economies, 2(2), 79-98.

George, G., McGahan, A. M., \& Prabhu, J. (2012). Innovation for inclusive growth: towards a theoretical framework and a research agenda. Journal of Management Studies, 49(4), 661-683.

Govindarajan, V., \& Trimble, C. (2012). Reverse innovation: create far from home, win everywhere. Boston: Harvard Business Press.

Gupta, A., \& Wang, H. (2010). Tata Nano: not just a car but also a platform. Retrieved October 31, 2014, from http://www.bloomberg.com/news/articles/ 2010-01-29/tata-nano-not-just-a-car-but-also-a-platform.

Gwet, K. L. (2014). Handbook of inter-rater reliability: the definitive guide to measuring the extent of agreement among raters (4th ed.). Gaithersburg: Advanced Analytics, LLC.

Hart, S. L., \& Christensen, C. M. (2002). The great leap. Sloan Management Review, 44(1), 51-56

Herstatt, C., Tiwari, R., \& Buse, S. (2008). India's national innovation system: key elements and corporate perspectives (Working Paper 51). Hamburg.

Howard, M. (2011). Will frugal innovation challenge the west? Market Leader. (Quarter 3), 53.

Immelt, J. R., Govindarajan, V., \& Trimble, C. (2009). How GE is disrupting itself. Harvard Business Review, 87(10), 56-65.

Jänicke, M. (2014). Frugale Technik. Ökologisches Wirtschaften-Fachzeitschrift, 29(1), $30-36$.

Jha, S. K., \& Krishnan, R. T. (2013). Local innovation: the key to globalisation. IIMB Management Review, 25(4), 249-256.

Kahle, H., Dubiel, A., Ernst, H., \& Prabhu, J. (2013). The democratizing effects of frugal innovation: implications for inclusive growth and state-building. Journal of Indian Business Research, 5(4), 220-234.

Krippendorff, K. (2004). Reliability in content analysis. Human communication research, 30(3), 411-433.

Kumar, N. (2008). Internationalization of Indian enterprises: patterns, strategies, ownership advantages, and implications. Asian Economic Policy Review, 3(2), 242-261.

Kumar, N., \& Puranam, P. (2012). Frugal engineering: an emerging innovation paradigm. Ivey Business Journal, 76(2). Retrieved November 01, 2014, from http://iveybusinessjournal.com/publication/frugal-engineering-an-emerginginnovation-paradigm/.

Leavy, B. (2014). India: MNC strategies for growth and innovation. Strategy \& Leadership, 42(2), 30-39.

Lehner, A.-C., \& Gausemeier, J. (2016). A pattern-based approach to the development of frugal innovations. Technology Innovation Management Review, 6(3), 13-21.

Lim, C., Han, S., \& Ito, H. (2013). Capability building through innovation for unserved lower end mega markets. Technovation, 33(12), 391-404.

Mandal, S. (2014). Frugal innovations for global health-perspectives for students. IEEE pulse, 5(1), 11-13.

Miles, M. B., Huberman, A. M., \& Saldaña, J. (2014). Qualitative data analysis: a methods sourcebook (3rd ed.). Thousand Oaks: Sage Publications.

Mukerjee, K. (2012). Frugal innovation: the key to penetrating emerging markets. Ivey Business Journal, 76(4). Retrieved November 01, 2014, from http:// iveybusinessjournal.com/publication/frugal-innovation-the-key-topenetrating-emerging-markets/.

Nocera, D. G. (2012). Can we progress from solipsistic science to frugal innovation? Daedalus, 141(3), 45-52.

Ojha, A. K. (2014). MNCs in India: focus on frugal innovation. Journal of Indian Business Research, 6(1), 4-28.

Oliver, W. (2013). Global construction equipment market: Chinese companies set the pace. New York: Oliver Wyman Group.

OLPC Association. (2015). Mission. Retrieved April 03, 2015, from http://one.laptop. org/about/mission.

Ostraszewska, Z., \& Tylec, A. (2015). Reverse innovation-how it works. International Journal of Business and Management, 3(1), 57-74

Pawlowski, J. M. (2013). Towards born-global innovation: the role of knowledge management and social software. In B. Janiūnaitè, A. Pundziene, \& M. Petraite (Eds.), Proceedings of the 14th European Conference on Knowledge Management. ECKM 2013: Kaunas University of Technology, Kaunas, Lithuania 5-6 September 2013 (pp. 527-534). Reading, UK: Academic Conferences and Publishing International Ltd.
Prabhu, G., \& Gupta, S. (2014). Heuristics of frugal service innovations. In Portland International Conference on Management of Engineering and Technology, Conference Proceedings 2014 (pp. 3309-3312). Kanazawa.

Prahalad, C. K. (2012). Bottom of the pyramid as a source of breakthrough innovations. Journal of Product Innovation Management, 29(1), 6-12.

Prahalad, C. K., \& Hart, S. L. (2002). The fortune at the bottom of the pyramid. strategy+business, 26, 54-67.

Prahalad, C. K., \& Mashelkar, R. A. (2010). Innovation's holy grail. Harvard Business Review, 88(7/8), 132-141.

Radjou, N., \& Prabhu, J. (2013). Frugal innovation: a new business paradigm. INSEAD Knowledge Publications, 1-3. Retrieved October 31, 2014, from http:// knowledge.insead.edu/innovation/frugal-innovation-a-new-businessparadigm-2375.

Radjou, N., \& Prabhu, J. C. (2014). Frugal innovation: how to do more with less (1st ed.). New York: PublicAffairs.

Radjou, N., Prabhu, J. C., \& Ahuja, S. (2012). Jugaad innovation: think frugal, be flexible, generate breakthrough growth (1st ed.). San Francisco: Jossey-Bass.

Ramdorai, A., \& Herstatt, C. (2015). Frugal innovation in healthcare: how targeting low-income markets leads to disruptive innovation. India studies in business and economics. Cham: Springer.

Rao, B. C. (2013). How disruptive is frugal? Technology in Society, 35(1), 65-73.

Rao, B. C. (2014). Alleviating poverty in the twenty-first century through frugal innovations. Challenge, 57(3), 40-59.

Ray, S., \& Ray, P. K. (2011). Product innovation for the people's car in an emerging economy. Technovation, 31(5-6), 216-227.

Saldaña, J. (2013). The coding manual for qualitative researchers (2nd ed.). Los Angeles: Sage Publications.

Sehgal, V., Dehoff, K., \& Panneer, G. (2010). The importance of frugal engineering. strategy+business, 59(Summer 2010), 1-5.

Sehgal, V., Dehoff, K., \& Panneer, G. (2011). Back to basics. Market Leader. (Quarter 1), 33-37.

Sekaran, U., \& Bougie, R. (2013). Research methods for business: a skill-building approach (6th ed.). Chichester, West Sussex: Wiley.

Sharma, A., \& lyer, G. R. (2012). Resource-constrained product development: implications for green marketing and green supply chains. Industrial Marketing Management, 41(4), 599-608.

Soni, P., \& Krishnan, R. T. (2014). Frugal innovation: aligning theory, practice, and public policy. Journal of Indian Business Research, 6(1), 29-47.

The Economist (2010). In praise of techno-austerity, 395(8686), 14. Retrieved October 29, 2014, from http://www.economist.com/node/16321516.

The Economist. (2012). Asian innovation: frugal ideas are spreading from east to west. Retrieved October 29, 2014, from http://www.economist.com/node/ 21551028.

Tiwari, R., \& Herstatt, C. (2012). Assessing India's lead market potential for costeffective innovations. Journal of Indian Business Research, 4(2), 97-115.

Tiwari, R., \& Herstatt, C. (2014). Aiming big with small cars: emergence of a lead market in India. India studies in business and economics. Heidelberg: Springer.

von Zedtwitz, M., Corsi, S., Søberg, P. V., \& Frega, R. (2015). A typology of reverse innovation. Journal of Product Innovation Management, 32(1), 12-28.

Williamson, P. J. (2010). Cost innovation: preparing for a 'value-for-money' revolution. Long Range Planning, 43(2-3), 343-353.

Wooldridge, A. (2010, April 17). First break all the rules: the charms of frugal innovation. The Economist, 3-5.

Zeschky, M., Widenmayer, B., \& Gassmann, O. (2011). Frugal innovation in emerging markets. Research-Technology Management, 54(4), 38-45.

Zeschky, M., Winterhalter, S., \& Gassmann, O. (2014). From cost to frugal and reverse innovation: mapping the field and implications for global competitiveness. Research-Technology Management, 57(4), 20-27. 